\title{
PaperitTomuUtTa VOI VÄHentäÄ VAIN TIETOA JA TUKEA TARJOAMALLA
}

Sirkka Mikkola: VTM, sosiaalityönstekijä

sirk.ka.mik.kola84@gmail.com

Janus vol. 27 (1) 2019, 79-87

JOHDANTO

Syksyllä 2015 Suomeen saapui ennätysmäärä, yli 30000 turvapaikanhakijaa, joista kaksi kolmasosaa Irakista. Suurin osa heistä on saanut tai tulee saamaan kielteisen turvapaikkapäätöksen. Jos he jäävät kielteisen päätöksen jälkeen Suomeen, heistä tulee paperittomia ihmisiä, jotka oleskelevat maassa ilman laillista oleskeluoikeutta. Paperittomuutta on monenlaista. Ihmisen oleskelulupa tai viisumi on saattanut vanhentua tai joskus oleskelulupaa ei ole lainkaan haettu.Turvapaikkajärjestelmä on kuitenkin synnyttänyt uuden kasvavan paperittomien alaryhmän, uuspaperittomat, jotka ovat kielteisen turvapaikkapäätöksen saaneita turvapaikanhakijoita. He elävät "puun ja kuoren välissä". Heitä ei voida viranomaistoimin palauttaa lähtömaihin, koska maiden välillä ei ole palautussopimusta. Esimerkiksi Irakin kanssa tällaista sopimusta ei ole, eikä Irak ota vastaan pakkopalautettua henkilöä.Vuoden 2015 turvapaikanhakijatilanteen vuoksi Suomessa on kiristetty turvapaikan ja muiden oleskelulupien saamisen ehtoja. Paperittomien määrän arvioidaankin kasvavan lähitulevaisuudessa 2000-4000:1la henkilöllä (Gadd 2017, 133-137; Jauhiainen 2017, 5-8, 12).

Paperittomat ovat haavoittuvassa asemassa oleva ihmisryhmä, jolla ei ole oi- keutta asuntoon, työntekoon eikä yhtä kattaviin sosiaali- ja terveyspalveluihin kuin oleskeluluvallisilla ihmisillä. Vuoden 2016 lopussa ministeriötyöryhmä antoi kunnille ohjeen turvata paperittomien oikeus välttämättömään toimeentuloon ja huolenpitoon. Ohjetta on tulkittu eri tavoin. Vuoden 2016 lopussa osa kunnista ei tarjonnut mitään palveluja paperittomille, kun taas toiset tarjosivat samat sosiaali- ja terveyspalvelut kuin muillekin kuntalaisille. Epätietoisuus siitä, millaisia palveluja paperittomille tulisi tarjota, on ollut voimakasta (Gadd 2017, 134-137, 140).

Epävarmuutta voimistanevat tavat, joilla paperittomista yhteiskunnassa puhutaan. Sisäministeriö on kehottanut puhumaan laittomasti maassa olevista, mikä liittää paperittomuuden herkästi rikollisuuteen. YK, Euroopan komissio ja Euroopan parlamentti sen sijaan ovat suositelleet käytettävän termejä "undocumented migrant" tai "irregular migrant", jotka eivät ota kantaa laillisuuskysymykseen (ks. Helsingin Diakonissalaitos 2017, 5-6). Käytän itse puheenvuorossani termiä paperiton, jolla viittaan turvapaikkaprosessin kautta paperittomaksi jääneisiin uuspaperittomiin, joita ei voida viranomaistoimin palauttaa lähtömaihin. Ennen vuoden 2015 lakimuutosta he saivat tilapäisen oleskeluluvan, mikä mahdollisti muun muassa työnteon. Lakimuutok- 
sen vuoksi heistä tulee nyt paperittomia.Vältän laiton-termin käyttöä myös siksi, että monella uuspaperittomalla on turvapaikkaprosessi vielä kesken, sillä he odottavat korkeimman hallinto-oikeuden lopullista päätöstä.

Epävarmuus paperittomille tarjottavista palveluista johtuu varmasti myös siitä, ettei paperittomien auttaminen tahdo istua saumattomasti yhteen viranomaistoiminnan kanssa. Paperittomuuden ja sosiaalityön välistä suhdetta Ruotsissa tutkineen Jessica Jönssonin (2014) mukaan paperittomien auttamisessa asettuvat ristiriitaan yhtäältä sosiaalityön ammattieettiset ohjeet ja kansainväliset ihmisoikeudet ja toisaalta kunnallinen lainsäädäntö ja viranomaisrooli. Tästä ambivalenssista johtuen osa sosiaalityöntekijöistä suhtautuu paperittomiin laittomasti maassa olevina rikollisina, joista tulee ilmoittaa poliisille. Toiset puolestaan näkevät heidät pikemminkin systeemin uhreina, joita tulee auttaa. Yhteistä ymmärrystä, asennetta ja ohjeita paperittomien kanssa työskentelyyn ei vielä ole (emt., 36-37, 44-48).

Puheenvuoroni perustuu uuspaperittomuutta käsittelevään sosiaalityön käytäntötutkimukseen, jonka tein Helsingin Maahanmuuttoyksikölle tammikuussa 2018 (Mikkola 2018). Yksikkö tarjoaa kotoutumista tukevia palveluja pakolaisille ja heihin rinnastettaville oleskeluluvan saaneille henkilöille Helsingissä. Keväästä 2017 yksikkö on ottanut asiakkuuteen myös paperittomia henkilöitä. Tutkimukseni tarkoituksena oli avata uuspaperittomien tuen tarpeita sekä muotoilla suuntaviivoja paperittomien sosiaalityölle Helsingissä. Tutkimustani varten haastattelin kahdessa moniammatillisessa fokusryhmässä seit- semää asiantuntijaa, joilla on kokemusta paperittomien kanssa työskentelystä. Haastatteluihin osallistui asiantuntijoita sosiaalityön, juridiikan, kriisityön, maahanmuuton, vaikuttamistyön ja avustustoiminnan aloilta. Osallistujat edustivat seuraavia organisaatioita: Helsingin kaupunki, Pakolaisneuvonta ry, Helsingin Diakonissalaitos, Suomen Punainen Risti, Suomen Mielenterveysseura ja Kotimajoitusverkosto.

\section{Paperittomilta puUttuvat RESURSSIT PÄÄTÖKSEN TEKEMISEKSI}

Yhteiskunnassamme paperittomuus nähdään ongelmana, joka halutaan poistaa. Myös käytäntötutkimukseeni osallistuneet asiantuntijat tietävät, että paperittomuus lisää inhimillistä ahdinkoa, hyväksikäyttöä, harmaata taloutta ja rikollisuutta. Tällä hetkellä paperittomuutta pyritään vähentämään ennen kaikkea houkuttelemalla kielteisen päätöksen saaneet turvapaikanhakijat palaamaan lähtömaihinsa. Kun päätös turvapaikanhakijan maasta poistamisesta on tullut täytäntöönpanokelpoiseksi, hänellä on 30 päivää aikaa palata lähtömaahan itsenäisesti tai hakea niin sanottua vapaaehtoista paluuta. Jos ihminen ei tartu tähän mahdollisuuteen eikä häntä voida viranomaistoimin palauttaa lähtömaahansa, hänen vastaanottopalvelunsa päättyvät 30 päivän kuluttua (Helsingin Diakonissalaitos 2017, 9-11). Vapaaehtoisen paluun tukea haetaan Maahanmuuttovirastolta tai vastaanottokeskuksesta ja kustannuksista vastaa IOM (International Organization of Migration). Tuen tarkoituksena on avustaa ihmistä rahallisesti tai tarvikkein ja palveluin uudelleen- 
kotoutumisessa lähtömaahan (MIGRI 2018; Sisäministeriön tiedote 97/2017).

Välttääkseen paperittomuuden tulisi kielteisen turvapaikkapäätöksen saaneen ihmisen siis kyetä tekemään suuria päätöksiä ja suunnitella elämänsä uudelleen varsin tiukalla aikataululla. Resurssit tähän ovat kuitenkin puutteelliset. Seuraavaksi erittelen syitä resurssien puuttumiseen, jotta nämä juurisyyt voitaisiin huomioida paperittomien kanssa tehtävässä sosiaalityössä.

\section{PuUtTeet toimintakyvyssä}

Kielteinen turvapaikkapäätös on ihmiselle shokki. Turvapaikanhakijat kärsivät hyvin yleisesti sotatraumoista ja moni on joutunut kotimaassaan kidutuksen uhriksi. Psyykkinen vointi on usein jo lähtökohtaisesti huono ja pitkäksi venynyt vastaanottokeskusaika on huonontanut sitä entisestään. Tätä taustaa vasten kielteinen päätös saattaa olla "se viimeinen pisara", joka romuttaa toimintakyvyn täysin. Shokkitila vaikeuttaa uutta elämäntilannetta koskevan tiedon omaksumista, päätöksen teosta ja elämän uudelleensuunnittelusta puhumattakaan. Haastateltavat ovat erityisen huolissaan turvapaikanhakijoiden ja paperittomien psyykkisestä voinnista ja heille tarjottavan psykiatrisen hoidon riittämättömyydestä.

Kielteisen turvapaikkapäätöksen psyykkiset vaikutukset ulottuvat kuitenkin usein alkuvaiheen shokkitilaa kauemmas. Päätös viestittää hakijalle, että hänen elämäntarinaansa ei olla uskottu tai hän ei ole tullut kuulluksi. Ihmisen on vaikea käsittää, että hänen kohtaamansa kauheat kokemukset eivät ole riittävä peruste turvapaikan saamiseksi. Tutkimukseen osallistunut sosiaalityöntekijä kuvaa kielteisen turvapaikkapäätöksen saaneen ihmisen kokemusmaailmaa seuraavasti:

"Sellainen täydellinen mitätöinti. Että mun tarinaani ei uskottu ja mua ei otettu vakavasti.Vähän semmoinen häpeä siitäkin.”

Nämä kokemukset ovat omiaan aiheuttamaan sarjan kielteisï tunteita. Tutkimuksessani tulevat esiin arvottomuuden, häpeän ja hylätyksi tulemisen kokemukset. Asiantuntijoiden mukaan paperittomaksi jääneet turvapaikanhakijat kokevat usein, että Suomi ja vastaanottokeskus ovat hylänneet heidät. "Suomi ei halua minua" on lause, jonka auttaja kuulee usein. Syitä kielteiseen päätökseen saatetaan etsiä omista henkilökohtaisista ominaisuuksista. Kuten yksi haastateltavista kuvailee, ajatellaan, että "minussa on jotain väärää".

Riitta Granfeltin (1998) mukaan on tyypillistä, että voimakkaita hylkäämisen kokemuksia osakseen saanut ihminen alkaa syyttää kohtalostaan itseään. Pidempään jatkuessaan itsesyytökset voivat heikentää ihmisen omanarvontuntoa ja sitä kautta toimintakykyä. Ihminen, jolta puuttuu käsitys omasta arvostaan, on altis tuntemaan häpeää, mikä on lamaannuttava tunne. Granfeltin mukaan kyse on sisäisestä kodittomuudesta, missä ihminen ei saa tuntumaa omaan sisimpäänsä, eikä siihen, mitä oikeasti ajattelee tai mihin haluaa pyrkiä (emt., 105-106, 141-142, 157). Paperittomaksi jääneellä turvapaikanhakijalla sisäinen kodittomuus on monikerroksista. Asiantuntijoiden mukaan perheen ja kotimaan jättäminen ovat turvapaikanhakijoille vaikeita päätök- 
siä, jotka aiheuttavat surua ja häpeää. Kielteinen turvapaikkapäätös ja ajatus kotiinpaluusta usein lisäävät häpeän tunnetta, etenkin jos koko suku on ollut mukana sponsoroimassa lähtijää.

Vaille turvapaikkaa jääminen nostattaa ihmisissä usein myös vihaa ja kokemusta siitä, että on tullut kohdelluksi epäoikeudenmukaisesti. Kokemus synnyttää voimakasta epäluottamusta Suomea ja sen viranomaisia kohtaan. Kuten Antti Kouvo $(2013,119)$ on todennut, viranomaisen taholta ihmiseen kohdistuva epäily ja epäreilu kohtelu synnyttävät epäluottamusta, joka kanavoituu paitsi viranomaisia, myös kanssaihmisiä kohtaan. Haastateltujen asiantuntijoiden mukaan paperittoman elämää alkaa sävyttää turvattomuuden tunne ja pelko kiinni jäämisestä, mistä syystä viranomaisten luokse ei uskalleta mennä. Usein epäluottamus laajenee koskemaan myös muita toimijoita, järjestöjä ja seurakuntia. Paperittomien elämää Suomessa tutkinut Katri Gadd (2017) puhuu pelon ja epäluottamuksen tunteista paperittomien toimintamahdollisuuksia heikentävinä henkisinä rajoitteina (emt., 139-140). Epäluottamus myös vähentää uskoa omiin toimintamahdollisuuksiin, ja siksi se voi aiheuttaa apatiaa ja passiivisuutta (ks. Salonen 2013, 141). Kun potentiaalisten auttajien luokse ei uskalleta mennä, turvautuvat paperittomat usein epävirallisiin tiedonlähteisiin. "Maanmiesten" keskuudessa ja sosiaalisessa mediassa liikkuu kuitenkin paljon väärää ja vanhentunutta tietoa, jonka varassa paperittomat jäsentävät elämäntilanteitaan.

Paperittomien asunnottomuus vaikeuttaa elämän suunnittelua entisestään.
Vastaanottopalveluiden päätyttyä paperittomaksi jääneellä turvapaikanhakijalla ei ole oikeutta asuntoon. Moni majoittuu milloin minnekin, usein ystävien tai sukulaisten nurkkiin. Tilapäistä hätämajoitusta vältellään viimeiseen asti, sillä se lisää psyykkistä kuormitusta. Yksi asiantuntijoista muistelee nuoren paperittoman miehen ensikosketusta asunnottomien yömajaan:

"Hän katsoo mua kauhu silmissään, että kuinka pian musta tulee tommonen? Milloin mun hampaat tippuu ja milloin musta tulee tommonen etten mä enää välitä, enkä enää peseydy? Ja sitten se paniikki, että en mä voi olla täällä ollenkaan. Että miten ne lyö vastaan ne palvelut, joita tarjotaan, siihen maailmankuvaan ja ihmiskuvaan ja käsitykseen itsestä ja Suomesta”.

Ihminen tarvitsee fyysisesti pysyvän tilan, jotta hän voi organisoida elämänsä ja saada riittävän rauhan vaihtoehtojen sisäistämiseen ja punnitsemiseen. Kriisityön asiantuntijan mukaan psyykkisesti huonovointisen ihmisen kohdalla jo se, että pitäisi päivän aikana kyetä olemaan jossain, ei ole helppoa. Granfeltin (1998) kodittomuuden käsitteen kautta tarkasteltuna näyttää siltä, että paperittoman ihmisen kohdalla konkreettinen asunnottomuus vahvistaa sisäisen kodittomuuden kokemusta. Se heikentää ihmisen omanarvontuntoa, mikä edelleen vaikeuttaa toimintamahdollisuuksia (ks. emt., 105-106).

\section{RIITTÄMÄTÖN INFORMAATIO}

Tutkimukseen osallistuneiden asiantuntijoiden mukaan paperittoman ymmärrys omasta tilanteestaan on usein puutteellinen. Hänellä on harvoin sel- 
keää käsitystä turvapaikkaprosessinsa vaiheesta tai kielteisen päätöksen perusteista. Vielä harvemmalla on tietoa muista mahdollisuuksista laillistaa oleskelu Suomessa. Kuten tutkimukseen osallistunut sosiaalityöntekijä toteaa:

"Ihan ensimmäiseks se, että heillä ei ole kokonaisvaltaista käsitystä siitä tilanteesta, että mikä se on ja mitkä ne oikeudet on. He eivät osaa kuvata sitä ollenkaan"

Vaikka tietoa olisikin tarjolla, ovat vaihtoehdot vähissä. Paperittomuus onkin elämäntilanteena äärimmäisen epätoivoinen. Valitus korkeimpaan hallintooikeuteen ei suojele ihmistä paperittomuudelta. Lisäksi lopullisen päätöksen valmistuminen kestää pitkään. Oleskeluluvan saaminen työn, opiskelun tai perheenyhdistämisen perusteella on kallista, haastavaa ja aikaa vievää sekä täynnä ehtoja, joita hakijan voi olla vaikea täyttää.

Ainoa mahdollisuus, mistä paperittomaksi jäänyt turvapaikanhakija näyttää olevan tietoinen on kotiinpaluu. Suurimmalle osalle paluu ei kuitenkaan ole vaihtoehto. Tutkimukseen osallistuneiden asiantuntijoiden mukaan kyse on yksinkertaisesti siitä, että ihmiset pelkäävät henkensä puolesta. Monella ei ole mitään, minne palata: kotikaupunki on pommitettu ja perhe tapettu. Paluu voi myös tuntua häpeälliseltä, kun lähtijään on satsattu paljon rahaa ja odotuksia. Kotijoukkojen puoleen kääntynyt paperiton saa vanhemmiltaan usein yksiselitteisen neuvon: älä palaa. Vanhempien auktoriteettia kunnioittavassa kulttuurissa tätä voi olla vaikea ohittaa.

Asiantuntijoiden mukaan paperittomilla on usein huonoja kokemuksia tilan- teista, joissa heille on kerrottu vapaaehtoisesta paluusta. Monet ovat kokeneet tilanteet painostavina. Kun ainoa tarjottu mahdollisuus on silkka mahdottomuus, kokee ihminen olevansa "motissa", vailla liikkumavaraa. Tämä tekee elämästä näköalatonta ja suunnitelmien tekemisestä lähes mahdotonta. Kuten Antti Särkelä (2001) huomauttaa, se millaisena näemme tulevaisuutemme, vaikuttaa siihen millaisia olemme nyt. Särkelän sanoin: "Toivottomalta näyttävä tulevaisuus tekee minusta toivottoman" (emt., 82).

Vaikka suurimmalla osalla turvapaikanhakijoista on lakimies, joka on valmistellut valitukset hallinto-oikeuteen ja mahdollisesti myös korkeimpaan hallinto-oikeuteen, ei omaa elämäntilannetta koskeva tieto ja ymmärrys näytä siirtyvän hakijalle itselleen. Oikeusavustaja ei ehkä ole selittänyt asioita riittävän hyvin tai ongelma on ollut kielimuurissa tai tulkkauksessa. Korkeimman hallinto-oikeuden päätöksen jälkeen julkinen oikeusapu lakkaa kokonaan. Tutkimuksessa haastatellun lakimiehen mukaan lakimiesyhteys saattaa myös passivoida asiakkaan. Juristin hoitaessa kaikki vaihteet asiakkaan puolesta ei tämä ole saanut omistaa prosessiaan. Tämä heikentää asiakkaan toimintavalmiuksia tilanteessa, jossa pitäisi alkaa tehdä päätöksiä itsenäisesti. Kulttuuriset tekijät voivat entisestään vaikeuttaa päätösten tekemistä. Usein turvapaikanhakijat tulevat maista, joissa vanhemmilla sukupolvilla on merkittävä päätösvalta nuorempien elämässä. Nuori irakilaismies ei välttämättä ole koskaan tehnyt pạätöksiä elämästään itsenäisesti. 
Paperitonta ihmistä tulee tukea RATKAISUN LÖYTYMISESSÄ

Tutkimukseen osallistuneiden asiantuntijoiden mielestä paperittomien jättäminen yhteiskunnan ulkopuolelle vaille palveluita ei ole oikea toimintamalli taistelussa paperittomuutta vastaan. Monelle paperittomuus on kuitenkin aina vähemmän huono vaihtoehto kuin kotiinpaluu. Jos paperittomuutta halutaan vähentää, paperittomille tulisikin tarjota riittävät resurssit vaihtoehtojen miettimiseen ja elämän uudelleensuunnitteluun. Omassa työssään asiantuntijat pyrkivät tarjoamaan asiakkailleen riittävästi aikaa ja rauhaa vaikeiden tunteiden käsittelemiseksi. Tämän jälkeen uutta elämäntilannetta koskevaa tietoa ja neuvontaa tarjotaan "tipoittain" pidemmän aikavälin kuluessa. Paperittomuuden alkuvaiheessa tuen tarve voi myös liittyä konkreettiseen tekemiseen. Kielteisen päätöksen aiheuttama shokkitila saattaa tehdä alun perin toimintakykyisestä ihmisestä täysin toimintakyvyttömän, jolloin hän tarvitsee ennen kaikkea tukea käytännön asioiden hoitoon.

Kun aikaa on kulunut muutama kuukausi, shokki alkaa usein lieventyä ja ihmisten suhtautuminen tilanteeseen muuttuu. Joku ottaa uudelleen harkintaan kotiinpaluun, mutta suurin osa alkaa miettiä keinoja laillistaa oleskelu Suomessa. Tässä kohtaa paperiton tarvitsisi ennen kaikkea riittävää ja ymmärrettävää oikeudellista neuvontaa eli tietoa oikeuksista, palveluista, oleskelulupien perusteista ja hakumenettelyistä. Vaihtoehdot ovat kuitenkin vähissä. Asiantuntijat pyrkivätkin työssään välttämään liiallista toivon herättämistä. Tässä suhteessa paperittomien kanssa tehtävä sosiaalityö eroaa muusta sosiaalityöstä, jonka ydintä on juuri toivon synnyttäminen (ks. Särkelä 2001, 82-86).

Toivon herättämisen sijaan haastateltavat puhuvat näköalojen avaamisesta ja elämäntilanteen selkeyttämisestä. Työskentelyn edetessä tämä parhaimmillaan mahdollistaa jonkinlaisen elämänsuunnitelman tekemisen. Tällä hetkellä paperittomalle tarjottu tieto on usein yksipuoleista ja kotiinpaluuseen painostavaa. Kaikenlainen työntekijän asiakkaaseen kohdistama painostus ja ohjailu kuitenkin helposti viestivät asiakkaalle, että häntä ei hyväksytä omana itsenään (Särkelä 2001, 31). Kuten edellä olen osoittanut, hyväksynnän ja kuulluksi tulemisen puute voivat entisestään heikentää ihmisen toimintakykyä. Särkelän (emt.) mukaan työntekijän tulisikin ennen kaikkea kuunnella asiakasta ja osoittaa ymmärtävänsä sitä, miten tämä itsensä ja tilanteensa kokee. Myös tavoitteiden suunnitteluun asiakas tulee ottaa mukaan, sillä se tuottaa positiivisia osallisuuden kokemuksia, mikä taas vahvistaa asiakkaan uskoa itseensä (emt., 29-30, 98). Kuten muussakin laadukkaassa sosiaalityössä, myös paperittomien kanssa tulisi lähteä liikkeelle asiakkaan omista merkityksenannoista. Tämä lähestymistapa tulee hyvin esille haastatteluun osallistuneen sosiaalityöntekijän puheenvuorossa:

"Enemmänkin pitää niin ku mennä siihen
tilanteeseen, että miks sä oot alun perin
lähtenyt ja mikä kotimaassa painaa. Et sen
pitäis olla sellaista keskustelutyyppistä, joka
voisi sitä ihmistä hyödyttääkin".

Asiantuntijoiden mukaan paperittomat tarvitsevat kipeästi kokemusta siitä, että 
heidät hyväksytään ja he saavat tukea tilanteeseensa. Haastatteluissa korostetaan tukiverkoston luomista ja kiinni pitävää työotetta. Luottamukseen ja hyväksyntään perustuvassa asiakassuhteessa ihminen voi alkaa punnita edessä olevia vaihtoehtoja. Kyse on korvaavan kiinni pitävän ympäristön luomisesta, jonka puitteissa ihminen voi alkaa vahvistaa sisäistä toimijuuttaan (ks. Granfelt 1998, 166, 177). Haastateltavat korostavat myös mielekkään tekemisen merkitystä. Toiminta tukee psyykkistä hyvinvointia ja auttaa tuomaan rakennetta arkeen. Lisäksi se synnyttää itsetunnolle tärkeitä onnistumisen kokemuksia ja tunteita omasta tarpeellisuudesta. Särkelän (2001) mukaan tällaiset kokemukset tuottavat positiivisempaa käsitystä omasta itsestä ja omista kyvyistä (emt.88-89). Yksi haastatelluista asiantuntijoista tarkastelee paperittomien kanssa tehtävää työtä juuri tästä näkökulmasta. Kyse on ihmisen voimaantumisesta ja oman paikan löytämisestä:

"Että me saatais heidät ulos siitä systeemistä, ei varjoina vaan näkyvinä värillisinä tyyppeinä, jotka joko löytää paikan täältä tai munalta. Mutta että heidän elämänsä ei oo pilalla!"

Lopulta, jotta paperittomaksi jäänyt turvapaikanhakija voisi suunnitella elämäänsä, tulisi asuminen järjestää eri tavalla ja turvata pidemmälle aikavälille. Asiantuntijoiden mukaan nykyinen hätämajoitusjärjestelmää lähinnä heikentää valmiuksia päätöksen tekoon ja lisää psyykkistä kuormitusta.

\section{LUOTTAMUKSEN RAKENTAMINEN}

JA SALASSAPITO

Tietoa ja tukea voidaan kuitenkin tarjota vasta, kun paperiton uskaltautuu niiden äärelle. Tämän vuoksi paperittomien yleisesti kokema epäluottamus pitäisi ottaa työskentelyn lähtökohdaksi. Asiantuntijat korostavat verkostoitumisen merkitystä. Kun tuntee tietyn organisaation toiminnan ja työntekijät, on helpompi vakuuttaa asiakas ja ohjata hänet eteenpäin oikealle taholle. Myös jalkautuva työote edistää luottamuksen rakentumista: mennään sinne missä paperittomat jo ovat ja tehdään kasvot tutuiksi.

Aina eivät auttajatkaan luota viranomaisiin, mistä syystä he eivät halua lähettää asiakkaitaan "koekaniineiksi" kunnan viranomaisten luo. Luottamusta tulisikin rakentaa myös auttajatahojen ja viranomaisten välille. Asiantuntijoiden mukaan tämä on mahdollista kuitenkin vasta, jos salassapito otetaan paperittomille tarjottavien sosiaali- ja terveyspalveluiden lähtökohdaksi. Niin sanotussa palomuurissa yhteiskunnan peruspalvelut erotetaan maahanmuuton kontrollitehtävästä, eikä viranomainen voi ilmiantaa asiakasta poliisille paperittomuuden perusteella. Tällaisessa tilanteessa paperiton voi alkaa luottaa lääkäriinsä ja sosiaalityöntekijäänsä ja saa tarvitsemansa avun. Tällöin myöskään paperitonta auttavan viranomaisen ei tarvitse tuntea epävarmuutta ja ristiriitaa roolissaan, minkä Jönssön (2014, 46-47) on tunnistanut Ruotsissa keräämässään aineistossa. PICUMIN (Platform for International Cooperation on Undocumented Migrants) asiantuntija Alyna Smith (2017) on Helsingissä luennoidessaan korostanut 
palomuurin merkitystä paperittomien oikeuksien turvaajana. Smithin mukaan palomuuri turvaisi paperittomien oikeuden elämään, terveyteen, yksityisyyteen ja syrjimättömyyteen.

Palveluista ja salassapidosta tulisi myös tiedottaa aiempaa avoimemmin. $\mathrm{Pa}-$ perittomien kanssa työskentelevät asiantuntijat ovat huomanneet, että kunnissa ollaan huolissaan niin sanotusta vetovoimatekijästä. Pelätään, että "liian hyvät palvelut" ja "liika tiedottaminen" houkuttelevat paperittomia kuntaan ja ylläpitävät paperittomuutta. Asiantuntijoiden mukaan kuitenkin vasta ihmisten hakeutuminen palvelujen piiriin tekee mahdolliseksi heidän auttamisensa ja sitä kautta paperittomuuden vähentämisen. Lisäksi se mahdollistaa tilastojen keräämisen, mikä tekee paperittomuuden uudella tavalla näkyväksi yhteiskunnassa.

\section{JOHTOPÄÄTÖKSET}

Vaille turvapaikkaa jääneiden ihmisten halutaan poistuvan Suomesta nopeasti. Palveluja ja mahdollisuuksia rajataan, jottei paperittomuudesta tulisi liian houkutteleva vaihtoehto. Monelle paperittomuus on kuitenkin vaihtoehto jo nyt, oli palveluita tarjolla tai ei. Palveluiden rajoittaminen saattaakin lopulta jopa ylläpitää paperittomuutta. Paperittomat nimittäin tarvitsisivat kipeästi tietoa ja tukea, jotta he voisivat löytää ratkaisun paperittomuudelle. Usein heillä ei ole riittävästi tietoa, eikä toimintakykyä ratkaisun tekemiseksi. Tilanteet pitkittyvät ja vaikeutuvat, sillä viranomaisten luokse ei uskalleta mennä. Paperittomien sosiaalityössä tulisikin puuttua juuri tähän epäkohtaan ja tarjota paperittomille mahdollisuus elämäntilanteen jäsentämiseen ja elämän uudelleensuunnitteluun luottamukseen ja hyväksyntään perustuvassa asiakassuhteessa.

\section{KirjallisuUs}

Gadd, Katri (2017) Paperittomat. Teoksessa Jussi S. Jauhiainen (toim.) Turvapaikka Suomesta? Vuoden 2015 turvapaikanhakijat ja turvapaikkaprosessit Suomessa. Turku:Turun yliopisto, 133-141.

Granfelt, Riitta (1998) Kertomuksia naisten kodittomuudesta. Helsinki: Suomalaisen kirjallisuuden seura.

Helsingin Diakonissalaitos (2017) Kohti järkeviä ratkaisuja. Uuspaperittomien tilanne, tuen tarve ja viisi toimenpideehdotusta. Helsingin Diakonissalaitoksen Suojattomat-hankkeen loppuraportti 2017. Helsinki: Helsingin Diakonissalaitos.

Jauhiainen, Jussi (2017) Johdanto ja johtopäätökset. Teoksessa Jussi Jauhiainen (toim.) Turvapaikka Suomesta? Vuoden 2015 turvapaikanhakijat ja turvapaikkaprosessit Suomessa. Turku: Turun yliopisto, 133-141.

Jönsson, Jessica (2014) Local Reactions to Global Problems: Undocumented Immigrants and Social Work. British Journal of Social Work 44 (1), 35-52. https://doi. org/10.1093/bjsw/bcu042

Kouvo, Antti (2013) Ihmisten välinen luottamus ruokajonojen ja asumispalveluyksikön asiakkailla. Teoksessa Mikko Niemelä \& Juho Saari (toim.) Huonoosaisten hyvinvointi Suomessa. Tampere: Kelan tutkimusosasto, 108-125.

MIGRI (2018) Voit saada tukea vapaaehtoiseen paluuseen. http://www.migri.fi/ turvapaikka_suomesta/paluu_kotimaahan Luettu 2.1.2018.

Mikkola, Sirkka (2018): Uuspaperittomien tuen tarpeet ja niihin vastaaminen. Asiantuntijoiden näkökulmia. Sosiaalityön käytäntötutkimus. Helsingin yliopisto.

Salonen, Anna-Sofia (2013) Kristillisen päihdetyön asiakkaiden hyvinvointi ja luottamuksen säröt. Teoksessa Mikko 
Niemelä \& Juho Saari (toim.) Huonoosaisten hyvinvointi Suomessa. Tampere: Kelan tutkimusosasto, 126-145.

Sisäministeriö (2017) Vapaaehtoisen paluun tukea korotetaan. Tiedote 97/2017. 21.9.2017. http://intermin.fi/artikkeli/-/asset_publisher/vapaaehtoisen-paluun-tukea-korotetaan Luettu 2.1.2018.
Smith, Alyna (2017) The "Firewall": An essential tool for safeguarding fundamental rights. PICUMIN (Platform for International Cooperation on Undocumented Migrants). Luento Helsingissä 15.11.17.

Särkelä, Antti (2008) Välittäminen ammattina. Näkökulmia sosiaaliseen auttamistyöhön. Tampere:Vastapaino. 